Brit. J. industr. Med., 1964, 21, 69.

\title{
LONG-TERM EFFECTS OF SULPHUR DIOXIDE EXPOSURE IN PULP MILLS
}

\author{
BY \\ INGAR O. SKALPE \\ From the Medical Department, Drammen Municipal Hospital, Drammen, Norway
}

(RECEIVED FOR PUBLICATION DECEMBER 1, 1962)

\begin{abstract}
This work is concerned with the problem of the chronic toxicity of sulphur dioxide in pulp mills. Fifty-four workers at four different pulp mills working in the acid towers and digester plants have been investigated with special regard to symptoms and signs of respiratory disease. Vital capacity has been measured with a ' Kifa' apparatus and maximal expiratory flow with a Wright peak flow meter. The concentration of sulphur dioxide in the working atmosphere has been measured during general working conditions on a single day, and the values were found to range between 2 and 36 parts per million.

The control group consisted of 56 paper industry workers from the same district with similar working conditions but working in an atmosphere free from objectionable gases. No significant difference in age or smoking habits was found between the groups.

A significantly higher frequency of cough, expectoration, and dyspnoea on exertion was found in the exposed group, the difference being greatest in age groups under 50 years. The average maximal expiratory flow rate was significantly lower $(P=0.05)$ in the exposed group than in those not exposed for men under 50 years. Over this age there was no significant difference between the two groups. Vital capacity values showed no significant difference between the groups.
\end{abstract}

The use of sulphur dioxide for industrial purposes is widespread, and much interest has been aroused regarding the chronic toxicity of this gas. It has a piercing smell, and by the unaccustomed it will be detected in concentrations down to 5 parts per million (p.p.m.) and a concentration of 10 p.p.m. will be found to be very disagreeable (Amdur, Melvin, and Drinker, 1953; Greenwald, 1954). The maximum allowable concentration in the industry has now been recommended in most countries as 5 p.p.m. (Barnes, 1961).

Many experimental studies on the chronic toxicity of sulphur dioxide have been performed, both on animals and on human subjects. According to Greenwald (1954) there seem to be great differences in the susceptibility of the different species, and man is found to be more sensitive to the gas than the other species studied. One of the most interesting experimental studies is that of Dalhamn and Rhodin (1956). They exposed rats to sulphur dioxide in a concentration of 10 p.p.m. for 10 weeks, and found this moderate exposure to give morphological and functional changes in the bronchial mucosa. The rate of mucus flow was considerably reduced, and the amount of secretion greatly increased. Histological examination of the bronchial mucosa showed multiplication of the mucus-secreting cells, which also is a characteristic finding in chronic bronchitis in man. Examination of the animals four weeks after the end of the exposure time showed no regression of the changes.

Amdur et al. (1953), in an experimental study on 14 healthy human subjects who were exposed to sulphur dioxide in concentrations of 1 to 8 p.p.m. for 10 minutes, found that the respiratory rate and the pulse rate increased and that the tidal volume decreased. These effects were not observed in two men who had frequently been exposed to sulphur dioxide in concentrations of 10 p.p.m. or more.

Frank, Amdur, Worcester, and Whittenberger (1962) exposed 11 male volunteers to average levels of sulphur dioxide of 1,5 , and 13 p.p.m. for 10 to 30 minutes. With one exception the group showed no significant increase in pulmonary flow resistance at 1 p.p.m., but at 5 and 13 p.p.m. flow resistance was elevated. There were no consistent changes in pulmonary compliance, tidal volume, respiratory rate or pulse rate. The functional residual capacity increased slightly during exposure to 13 p.p.m. 
Only a few controlled clinical studies have been reported. Kehoe, Machle, Kitzmiller, and LeBlanc (1932) examined 100 workers in a refrigerator factory exposed to sulphur dioxide in concentrations of 20 to 30 p.p.m. throughout the working day, comparing this group with an unexposed control group in the same factory. In the exposed group there was a significantly higher incidence of nasopharyngitis and dyspnoea on exertion than in the control group. Anderson (1950) studied workers at an oil refinery, who were exposed to sulphur dioxide in concentrations of 0 to 20 p.p.m., and compared the group with an unexposed control group in the same factory. He could find no adverse effects on health caused by the sulphur dioxide exposure. In both these studies chest radiographs were taken; Anderson also registered the vital capacity.

Greenwald (1954) states in a review on the subject that the evidence regarding chronic intoxication is conflicting, and that occasional exposure to high concentrations seems to be less harmful than continuous exposure to lower concentrations.

The present work is concerned with the chronic toxicity of sulphur dioxide in pulp mills. The work was stimulated by the observation that pulp mill workers in the digester plants, where the wood chips are digested by sulphur dioxide, very often complain of chronic cough. An attempt has therefore been made to find out whether there is a higher incidence of respiratory disease in a group of these workers than in a comparable unexposed control group.

\section{Material}

The exposed group consisted of workers at four different pulp mills who were working in the acid towers and digester plants. The degree of contamination with sulphur dioxide in these pulp mills was estimated with the kind assistance of Dr. A. Bruusgaard and Dr. O. Dischington Hansen, of the State Labour Inspection Services, Oslo. Tests were taken with Dräger-Gas-Spürgerät, Modell $19 / 31$, at different times on a single ordinary working day. The results are given in Table 1 . The values

TABLE 1

SULPHUR DIOXIDE CONCENTRATIONS (P.P.M.) UNDER GENERAL WORKING CONDITIONS IN THE ACID TOWER AND DIGESTER PLANT OF FOUR PULP MILLS. TESTS TAKEN AT DIFFERENT TIMES ON A SINGLE DAY

\begin{tabular}{l|r|c|c|c}
\hline \multirow{2}{*}{ Location of Air Sample } & \multicolumn{3}{|c}{ Pulp Mill } \\
\cline { 2 - 5 } & I & II & III & IV \\
\hline Acid tower & 10 & & & 14 \\
& 19 & & & 17 \\
& 36 & & & 10 \\
\hline Digester plant & & & & \\
$\begin{array}{l}\text { Top floor } \\
\text { Middle floor } \\
\text { Bottom floor }\end{array}$ & 3 & 12 & 10 & $1-2$ \\
& 12 & 14 & 5 & $1-2$ \\
& & 19 & & \\
\hline
\end{tabular}

ranged between 2 and 36 p.p.m. Only readings made under general working conditions have been noted. Special procedures, such as 'blowing the digesters', led to concentrations up to 100 p.p.m., but this lasted only a few minutes and airway irritation was so intense that the workers had to use gas masks. Accidental intoxication during these procedures leading to serious bronchitis has been seen in our department, but this problem is beyond the scope of the present study.

It must be taken into account that these estimations only give an impression of present-day conditions. In recent years much has been done to reduce the sulphur dioxide concentration in the atmosphere in the working areas, and it must be supposed that many of the workers concerned in the present investigation have had a much heavier exposure than is indicated by the present analyses.

The control group consisted of indoor paper industry workers, partly from the same factories as the exposed group and partly from paper mills in the same district, chosen from plants with no objectionable gases in the atmosphere and where the work involved about the same degree of physical activity as in the exposed group. Information regarding previous work was asked for, and a few workers who had been exposed to sulphur dioxide in a previous job were excluded.

Factors known to influence the results reported are age and smoking habits (Read and Selby, 1961). Tables 2 and 4 show that there are no significant differences in age or in the frequency of smokers between the two groups. There were four ex-smokers in the control group and three in the exposed group. All of them had stopped smoking.

TABLE 2

COMPARISON OF GROUPS BY AGE

\begin{tabular}{l|c|c}
\hline Age Group & Exposed Group & Controls \\
\hline $20-30$ & 6 & 5 \\
$30-40$ & 12 & 17 \\
$40-50$ & 26 & 12 \\
\hline Total & $38 \cdot 6$ & 34 \\
\hline Mean (yr.) & 14 & $41 \cdot 7$ \\
S.D. & 11 \\
\hline Difference (yr.) & & $3 \cdot 1$ \\
S.E. of difference & & \\
\hline $50-60$ & 13 & 12 \\
60-70 & 15 & 10 \\
\hline Total & 28 & 22 \\
\hline Mean (yr.) & $60 \cdot 0$ & $60 \cdot 8$ \\
S.D. & 12 & 12 \\
\hline Difference (yr.) & & $0 \cdot 8$ \\
S.E. of difference & & \\
\hline
\end{tabular}

seven years or more before the examination, and they are included in the 'non-smoker' group. The average consumption of tobacco was the same in the two groups, about $50 \mathrm{~g}$. per week. No significant difference in the frequency of cigarette smokers was found, as $77 \%$ of the smokers in the exposed group and $75 \%$ in the control group smoked cigarettes (difference $3 \% ;$ S.E. of difference $=8$ ). The socio-economic status should be about the 
same, as both groups consisted of shift workers in the same kind of industry.

Examination was arranged as a routine check-up in the surgery of each factory, and the workers were called in by the same employee who was in charge of calling them in for their yearly check-up. All the workers in the acid towers and the digester plants at the four pulp mills were called in for examination, and there were only two or three lapses at each factory due to incidental illness at the time of the investigation. For the same reason there were also a few lapses in the control group.

\section{Methods}

All the workers have been examined by the author. They have been thoroughly examined regarding the three main symptoms of respiratory disease: cough, expectoration, and dyspnoea. The first question was: 'Are you troubled by cough?' If the answer was 'no', it was checked by asking: 'Not in the morning, either?' Those who answered 'yes' to any of these questions were examined further on their cough, and only those admitting to chronic cough almost all the year, or to periods of cough almost every year lasting several months, were registered.

Those who answered 'yes' to the questions on cough were asked: 'Do you usually bring up any phlegm on coughing?' Those who answered 'yes' were examined further, and only those admitting to chronic phlegm almost all the year, or to periods of phlegm almost every year lasting several months, were registered.

The following phrasing was used in the examination on dyspnoea: 'When walking together with other people of your own age, do you get more short of breath than they do?' Only those who answered a definite 'yes' to this question were registered.

According to earlier investigations (Anderson, 1950; Kehoe et al., 1932), chest radiographs were not expected to give information of any value. The cbjective examination was confined to the registration of vital capacity (V.C.) and maximal expiratory flow rate (M.E.F.R.). V.C. was registered with a 'Kifa' apparatus, which has a very small resistance. M.E.F.R. was measured with Wright's peak flow meter. This flow meter has been used in extensive investigations, and the results have shown a good correlation with the forced expiratory volume (F.E.V.) in men (Higgins, 1957). Fletcher, Fry, Oswald, and Reid (1961) found the results to be more variable in women. The method therefore seemed particularly well suited to the present investigation. Each worker performed a series of five maximal forced expirations into the peak flow meter, and the mean of the three highest values was used in the results.

\section{Results}

As V.C. and M.E.F.R. fall with increasing age, the material is divided into two age groups, over and under 50 years. This division also takes the exposure time into account, because almost all the workers under 50 had been exposed less than the mean exposure time, and almost all the workers over 50 had been exposed longer. The exposure time for the different age groups is given in Table 3.

TABLE 3

LENGTH OF EXPOSURE TO SULPHUR DIOXIDE IN A GROUP OF 54 PULP MILL WORKERS

\begin{tabular}{l|c|c}
\hline \multicolumn{1}{c|}{ Age Group } & Mean (yr.) & Variability \\
\hline $\begin{array}{l}\text { Under } 50 \\
\text { Over } 50\end{array}$ & $\begin{array}{c}6.8 \\
20 \cdot 3\end{array}$ & $\begin{array}{l}1 \mathrm{mth} .-27 \mathrm{yr} . \\
2 \mathrm{yr} .44 \mathrm{yr} .\end{array}$ \\
\hline Total & $13 \cdot 8$ & \\
\hline
\end{tabular}

From Table 4 it is seen that the frequency of cough, expectoration, and dyspnoea on exertion is much higher in the exposed group than in the control group. The difference is greatest in age groups under 50 years, being four to five times the standard error. In age groups over 50 years the difference is twice the standard error.

TABLE 4

SYMPTOMS OF RESPIRATORY DISEASE AND SMOKING HABITS IN A GROUP OF PULP MILL WORKERS EXPOSED TO SULPHUR DIOXIDE, AND IN AN UNEXPOSED CONTROL GROUP

\begin{tabular}{|c|c|c|c|c|c|c|c|c|c|c|}
\hline \multirow{2}{*}{ Age Group } & & \multirow{2}{*}{ No. in Group } & \multicolumn{2}{|c|}{ Cough } & \multicolumn{2}{|c|}{ Sputum } & \multicolumn{2}{|c|}{ Dyspnoea } & \multicolumn{2}{|c|}{ Smokers } \\
\hline & & & No. & $\%$ & No. & $\%$ & No. & $\%$ & No. & $\%$ \\
\hline \multirow[t]{2}{*}{ Under 50} & $\begin{array}{l}\text { Exposed } \\
\text { Not exposed }\end{array}$ & $\begin{array}{l}26 \\
34\end{array}$ & $\begin{array}{r}16 \\
2\end{array}$ & $\begin{array}{l}62 \\
0 \cdot 6\end{array}$ & $\begin{array}{r}12 \\
1\end{array}$ & $\begin{array}{l}46 \\
0 \cdot 3\end{array}$ & $\begin{array}{l}7 \\
2\end{array}$ & $\begin{array}{l}27 \\
0 \cdot 6\end{array}$ & $\begin{array}{l}18 \\
25\end{array}$ & $\begin{array}{l}70 \\
74\end{array}$ \\
\hline & $\begin{array}{l}\text { Difference } \\
\text { S.E. of difference }\end{array}$ & & 14 & $\begin{array}{l}61 \\
11\end{array}$ & 11 & $\begin{array}{l}46 \\
11\end{array}$ & 5 & $\begin{array}{r}26 \\
9\end{array}$ & 7 & $\begin{array}{l}4 \\
9\end{array}$ \\
\hline \multirow[t]{2}{*}{ Over 50} & $\begin{array}{l}\text { Exposed } \\
\text { Not exposed }\end{array}$ & $\begin{array}{l}28 \\
22\end{array}$ & $\begin{array}{r}14 \\
5\end{array}$ & $\begin{array}{l}50 \\
22\end{array}$ & $\begin{array}{r}13 \\
2\end{array}$ & $\begin{array}{r}46 \\
9\end{array}$ & $\begin{array}{l}5 \\
1\end{array}$ & $\begin{array}{r}18 \\
5\end{array}$ & $\begin{array}{l}18 \\
15\end{array}$ & $\begin{array}{l}64 \\
68\end{array}$ \\
\hline & $\begin{array}{l}\text { Difference } \\
\text { S.E. of difference }\end{array}$ & & 9 & $\begin{array}{l}28 \\
14\end{array}$ & 11 & $\begin{array}{l}37 \\
12\end{array}$ & 4 & $\begin{array}{r}13 \\
9\end{array}$ & 3 & $\begin{array}{r}4 \\
14\end{array}$ \\
\hline \multirow[t]{2}{*}{ Total } & $\begin{array}{l}\text { Exposed } \\
\text { Not exposed }\end{array}$ & $\begin{array}{l}54 \\
56\end{array}$ & $\begin{array}{r}30 \\
7\end{array}$ & $\begin{array}{l}56 \\
13\end{array}$ & $\begin{array}{r}25 \\
3\end{array}$ & $\begin{array}{r}46 \\
5\end{array}$ & $\begin{array}{r}12 \\
3\end{array}$ & $\begin{array}{r}22 \\
5\end{array}$ & $\begin{array}{l}36 \\
40\end{array}$ & $\begin{array}{l}67 \\
71 \\
\end{array}$ \\
\hline & $\begin{array}{l}\text { Difference } \\
\text { S.E. of difference }\end{array}$ & & 23 & $\begin{array}{r}43 \\
9\end{array}$ & 22 & $\begin{array}{r}41 \\
8\end{array}$ & 9 & $\begin{array}{r}17 \\
7\end{array}$ & 16 & $\begin{array}{l}4 \\
9\end{array}$ \\
\hline
\end{tabular}


TABLE 5

VITAL CAPACITY VALUES IN A GROUP OF PULP MILL WORKERS EXPOSED TO SULPHUR DIOXIDE AND IN AN UNEXPOSED CONTROL GROUP

\begin{tabular}{|c|c|c|c|c|}
\hline \multirow{2}{*}{ V.C. (1.) } & \multicolumn{2}{|c|}{ Under $50 \mathrm{yr}$. } & \multicolumn{2}{|c|}{ Over 50 yr. } \\
\hline & Exposed & Controls & Exposed & Controls \\
\hline $\begin{array}{l}2.2 \\
2.4 \\
2.6 \\
2.8 \\
3.0 \\
3.2 \\
3.4 \\
3.6 \\
3.8 \\
4.0 \\
4.2 \\
4.4 \\
4.6 \\
4.8 \\
5.0 \\
5.2 \\
5.4\end{array}$ & $\begin{array}{l}1 \\
1 \\
1 \\
3 \\
5 \\
2 \\
3 \\
4 \\
2 \\
3 \\
1\end{array}$ & $\begin{array}{l}4 \\
3 \\
5 \\
3 \\
3 \\
1 \\
7 \\
2 \\
2 \\
2 \\
2\end{array}$ & $\begin{array}{l}1 \\
3 \\
1 \\
2 \\
3 \\
4 \\
5 \\
1 \\
3 \\
3 \\
1 \\
1 \\
1\end{array}$ & $\begin{array}{l}1 \\
2 \\
2 \\
1 \\
3 \\
2 \\
2 \\
4 \\
3 \\
2\end{array}$ \\
\hline Total & 26 & 34 & 28 & 22 \\
\hline $\begin{array}{l}\text { Mean } \\
\text { S.D. }\end{array}$ & $\begin{array}{l}3.98 \\
0.62\end{array}$ & $\begin{array}{l}4 \cdot 18 \\
0 \cdot 68\end{array}$ & $\begin{array}{l}3.36 \\
0.63\end{array}$ & $\begin{array}{l}3.40 \\
0.67\end{array}$ \\
\hline \multicolumn{2}{|c|}{$\begin{array}{l}\text { Difference } \\
\text { S.E. of difference }\end{array}$} & & \multicolumn{2}{|c|}{$\begin{array}{l}0.04 \\
0 \cdot 18\end{array}$} \\
\hline
\end{tabular}

TABLE 6

MAXIMAL EXPIRATORY FLOW RATES IN A GROUP OF PULP MILL WORKERS EXPOSED TO SULPHUR DIOXIDE AND IN AN UNEXPOSED CONTROL GROUP

\begin{tabular}{|c|c|c|c|c|}
\hline \multirow{2}{*}{$\begin{array}{l}\text { M.E.F.R. } \\
\text { (1./min.) }\end{array}$} & \multicolumn{2}{|c|}{ Under 50 yr. } & \multicolumn{2}{|c|}{ Over 50 yr. } \\
\hline & Exposed & Controls & Exposed & Controls \\
\hline $\begin{array}{l}250 \\
300 \\
350 \\
400 \\
450 \\
500 \\
550 \\
600 \\
650\end{array}$ & $\begin{array}{r}1 \\
2 \\
1 \\
1 \\
3 \\
13 \\
2 \\
4\end{array}$ & $\begin{array}{r}1 \\
2 \\
7 \\
18 \\
2 \\
3\end{array}$ & $\begin{array}{l}1 \\
1 \\
7 \\
8 \\
7 \\
2 \\
2\end{array}$ & $\begin{array}{l}1 \\
1 \\
3 \\
4 \\
2 \\
5 \\
2 \\
3 \\
1\end{array}$ \\
\hline Total & 26 & 34 & 28 & 22 \\
\hline $\begin{array}{l}\text { Mean } \\
\text { S.D. }\end{array}$ & $\begin{array}{r}509 \\
84\end{array}$ & $\begin{array}{r}551 \\
75\end{array}$ & $\begin{array}{r}482 \\
77\end{array}$ & $\begin{array}{l}481 \\
100\end{array}$ \\
\hline \multicolumn{2}{|c|}{$\begin{array}{l}\text { Difference } \\
\text { S.E. of difference }\end{array}$} & $\begin{array}{l}42 \\
21\end{array}$ & \multicolumn{2}{|c|}{$\begin{array}{r}1 \\
26\end{array}$} \\
\hline
\end{tabular}

Table 5 shows that no difference in values for V.C. could be found between the groups. The results of M.E.F.R. measurements are given in Table 6. In the age groups under 50 there was a difference in means of $42 \mathrm{1}$./min., which is twice the standard error. In the age groups over 50 no difference in M.E.F.R. values could be found.

\section{Discussion}

The most convincing result of the investigation is the extraordinarily high frequency of symptoms of respiratory disease in the exposed group, especially in the age group under 50 years. M.E.F.R. values in the age group under 50 showed lower values in the exposed group, the difference being twice the standard error, which is usually considered as statistically significant. Another indication that this difference is real is that it corresponds with the difference in symptoms between the groups.

As shown above, the most obvious reasons for incomparability between the groups, such as difference in age, smoking habits, climatic conditions, working conditions, and socio-economic status, have been avoided. Another important factor that would influence the comparability is variation between different observers, but as all the workers have been examined by the author, this factor is eliminated. The controls and the exposed workers were examined alternately in small groups over a short period of time. Variation in the author's diagnostic level during the survey period is therefore probably small and should influence both groups equally. Unfortunately, for practical reasons, the interviewer at the time of the examination had to know who was exposed to sulphur dioxide and who was not. This might, of course, have led to a statistical bias, but it seems that the difference in the prevalence of symptoms of respiratory disease between the two groups is too great for this to be the only explanation.

A comparison of the prevalence of symptoms of respiratory disease in the present control group and in a group of Norwegian workers reported by Mork (1962), in a comparative study of respiratory disease in England and Wales and in Norway, shows a much higher frequency of cough, phlegm, and dyspnoea in Mork's group. He finds, for instance, that one third of the men had morning cough lasting for three months or more each winter. Some difference might be expected due to the selection of the groups. The group examined by Mork consisted mainly of outdoor maintenance workers, bus divers, and conductors living in a moist climate in an urban community on the west coast of Norway, whereas the author's control group consisted of indoor paper industry workers living in a dry inland climate in a more rural community. Smoking habits seemed to be similar in the two groups, with about the same proportion of cigarette smokers. However, as the studies were carried out by different observers using different methods of questioning, the comparability of the results is very restricted. As shown by Fairbairn et al. (1959, cited by Mork, 1962), even the use of the same standardized questionnaire by different interviewers may give considerable differences in the results. Difference in the diagnostic level might therefore be an important reason for the great differences found between the two groups.

It is surprising that the differences found in the present study are greatest in the age groups under $\mathbf{5 0}$ 
years where the exposure time has been shortest. One possible explanation of this is that in the younger age groups there are workers who are less tolerant to sulphur dioxide and therefore have to find other places of work before they reach the fifties. According to the older workers, the working stock was very stable, and a worker rarely had to leave because of intolerance to sulphur dioxide. Another possible explanation is that the difference is due to acclimatization to the gas, because it is well known that experienced workers can hardly detect concentrations which are intolerable for a new worker. However, this acclimatization takes only a few months (Anderson, 1950), and almost all the workers in the younger age group had been exposed more than a year. In my opinion, a more likely explanation is that because respiratory disease is rare in the younger age groups, the effect of small, exogenous trauma is easier to detect than in the older age groups where respiratory disease from other causes is more common, so that a small addition will be less noticeable.

\section{Conclusion}

Exposure to sulphur dioxide in the pulp mills investigated seems to have caused a significantly higher incidence of symptoms of respiratory disease in a group of exposed workers than in a comparable control group. The average M.E.F.R. was significantly lower $(P=0.05)$ in the exposed group than in those not exposed in age groups under 50 years. Over this age there was no significant difference between the two groups. Vital capacity values showed no significant difference between the groups.

\section{REFERENCES}

Amdur, M. O., Melvin, W. W., and Drinker, P. (1953). Lancet, 2, 758. Anderson, A. (1950). Brit. J. industr. Med., 7, 82

Barnes, J. M. (1961). Brit. med. J., 2, 1097.

Dalhamn, T., and Rhodin, J. (1956). Brit. J. industr. Med., 13, 110.

*Fletcher, C. M., Fry, J., Oswald, N. C., and Reid, D. D. (1961). Brit. med. J., $2,973$.

Frank, N. R., Amdur, M. O., Worcester, J., and Whittenberger, J. L. (1962). J. appl. Physiol., 17, 252.

Greenwald, I (i954) Arch industr. Hyg 10, 455.

Greenwald, I. (1954). Arch. industr. Hyg., 10, 45

Higgins, I. T. T. (1957). Brit. med. J., 2, 1198. Kehoe, R. A., Machle, W. F., Kitzm.

Mork, T. (1962). A Comparative Study of Respiratory Disease in England and Wales and Norway. Norwegian Universities Press, Oslo, Acta med. scand., Suppl. 384.

Read, J. and Selby, T. (1961). Brit. med. J., 2, 1104.

* Survey made by Coll. of Gen. Practit. Report prepared by Fletcher, Fry, Oswald and Reid. 